\title{
MENINGKATKAN KEMAMPUAN MEMBACA PUISI MELALUI PENERAPAN PEMBELAJARAN KONTEKSTUAL SISWA KELAS V SDN 8 KUSAMBI
}

\author{
Bahtiar $^{1)}$, La Rabani ${ }^{2)}$. \\ ${ }^{1)}$ SDN 8 Kusambi, Muna Barat, Indonesia \\ ${ }^{2)}$ Jurusan PGSD, Universitas Halu Oleo, Kendari, Indonesia \\ email: larabani59@gmail.com
}

\begin{abstract}
Abstrak: Jenis penelitian ini adalah penelitian tindakan kelas yang berusaha mengkaji masalah-masalah tertentu dan tindakan yang dilakukan oleh peneliti dalam proses pembelajaran untuk meningkatkan kemampuan membaca puisi siswa kelas V SD melalui penerapan pembelajaran kontekstual. Hasil yang diperoleh dari penelitian ini yaitu dari kemampuan membaca puisi mengalami peningkatan yakni pada tindakan siklus I nilai ketuntasan secara klasikal adalah $45 \%$ dan nilai ratarata siswa mencapai 65,05 . Pada siklus II hasil belajar siswa untuk kemampuan membaca puisi mengalami peningkatan yakni nilai ketuntasan secara klasikal adalah $85 \%$ yang telah memenuhi Kriteria Ketuntasan Minimal (KKM) 70, dan nilai rata-rata siswa mencapai 77,85 . Pada siklus I pertemuan pertama aktivitas guru mencapai $47,05 \%$, dan pada pertemuan kedua mencapai $58,82 \%$. Pada siklus II pertemuan pertama aktivitas guru meningkat menjadi $64,70 \%$, dan pada pertemuan kedua mencapai $94,11 \%$. Dan aktivitas belajar siswa pada siklus I pertemuan pertama mencapai $45,45 \%$ dan pertemuan kedua $54,54 \%$. Pada siklus II pertemuan pertama mencapai $72,72 \%$ dan meningkat pada pertemuan kedua mencapai $90,90 \%$.
\end{abstract}

Kata Kunci: Model Pembelajaran Kontekstual; Kemampuan Membaca; Puisi.

\section{IMPROVING THE ABILITY OF READING POETRY THROUGH THE IMPLEMENTATION OF CONTEXTUAL LEARNING STUDENTS OF CLASS V SDN 8 KUSAMBI}

\begin{abstract}
This type of research is a classroom action research which seeks to examine certain problems and the actions taken by researchers in the learning process to improve the poetry reading skills of fifth grade elementary school students through the application of contextual learning. The results obtained from this study, namely the ability to read poetry has increased, namely in the action cycle I classical completeness value was $45 \%$ and the average score of students reached 65.05. In cycle II student learning outcomes for the ability to read poetry have increased, namely the classical completeness value is $85 \%$ which has met the Minimum Completion Criteria (KKM) 70, and the student's average score reaches 77.85. In the first cycle of the first meeting, the teacher's activity reached $47.05 \%$, and at the second meeting it reached $58.82 \%$. In the second cycle of the first meeting, the teacher's activity increased to $64.70 \%$, and at the second meeting it reached $94.11 \%$. And student learning activities in the first cycle of the first meeting reached $45.45 \%$ and the second meeting $54.54 \%$. In the second cycle the first meeting reached $72.72 \%$ and an increase in the second meeting reached $90.90 \%$.
\end{abstract}

Keywords: Contextual Learning Model; Reading Ability; Poetry. 


\section{Pendahuluan}

Salah satu keterampilan yang diharapkan dimiliki oleh siswa dari sekolah dasar adalah keterampilan berbahasa yang baik, karena bahasa merupakan modal terpenting bagi manusia. Dalam pengajaran bahasa Indonesia, ada empat keterampilan berbahasa yang harus dimiliki oleh siswa, yaitu keterampilan mendengarkan, berbicara, membaca, dan menulis. Keempat aspek berbahasa ini saling terkait; seorang anak, misalnya, akan bisa menceritakan sesuatu setelah ia membaca ataupun setelah ia mendengarkan (Susanto, 2014:241).

Menurut BSNP (Susanto, 2014:245), pembelajaran bahasa Indonesia diarahkan untuk meningkatkan kemampuan siswa untuk berkomunikasi dalam bahasa Indonesia dengan baik dan benar, baik secara lisan maupun tulis, serta menumbuhkan apresiasi terhadap hasil karya kesastraan manusia Indonesia. Sejalan dengan itu, Budianta (2002:20) berpendapat bahwa sastra memiliki kegunaan sebagai media komunikasi dalam kehidupan sehari-hari, seperti penggunaan puisi untuk menyatakan perasaan cinta, marah, sedih, atau benci. Sastra melibatkan tiga komponen yaitu pengarang sebagai pengirim pesan, karya sastra sebagai pesan itu sendiri dan penerima pesan yaitu pembaca karya sastra maupun pembaca yang tersirat dalam teks atau yang dibayangkan oleh pengarang.

Pembelajaran sastra dilakukan dalam berbagai jenis dan bentuk melalui kegiatan mendengarkan, berbicara, membaca dan menulis. Hal ini menunjukkan bahwa penguasaan sastra mengacu pada kemampuan empat aspek keterampilan berbahasa. Pembelajaran puisi yang diajarkan di Sekolah Dasar merupakan salah satu materi pembelajaran sastra yang lebih sulit dan banyak menimbulkan masalah dibandingkan membaca karya sastra lainnya. Pembelajaran membaca puisi yang seharusnya menyenangkan ternyata membosankan dan sekaligus menakutkan, baik guru dan siswa (Sakdiyah, 2001:48).

Pembelajaran membaca puisi adalah bagian dari pembelajaran apresiasi sastra. Pembelajaran apresiasi sastra merupakan proses antara guru dan siswa, yang menjadikan proses pengenalan, pemahaman dan penghayatan. Pada akhirnya dalam menikmati karya sastra akan mampu menerapkan di dalam kehidupan sehari-hari. Pembelajaran sastra khususnya puisi dalam kegiatan belajar belum diupayakan secara maksimal, karena sebenarnya pembelajaran puisi merupakan kegiatan pementasan karya seni yang memerlukan kemampuan khusus.

Pembelajaran puisi dengan pelafalan dan intonasi yang tepat sering mengalami kendala. Kendala tersebut antara lain: (1) pengaruh dialek bahasa lokal, (2) kurang adanya percaya diri, dan (3) minimnya contoh pembacaan puisi yang benar. Guru bahasa Indonesia sendiri belum tentu memiliki kemampuan membaca puisi yang baik dan benar, sehingga pembelajaran yang dilakukan lebih bersifat teoretis.

Kuatnya pengaruh dialek bahasa lokal, menjadikan pembacaan puisi sebagai bahan tertawaan karena terdengar lucu. Kurangnya rasa percaya diri menyebabkan siswa malu untuk maju ke depan kelas dan merasa terpaksa. Minimnya contoh membaca puisi dengan lafal dan intonasi yang tepat membuat siswa tidak memiliki acuan atau gambaran tentang membaca puisi yang tepat. Kendala-kendala di atas menyebabkan siswa belum dapat membaca puisi dengan baik dan benar sesuai kompetensi dasar yang ditentukan.

Berdasarkan hasil observasi awal, menunjukkan bahwa hasil belajar bahasa Indonesia khususnya kemampuan membaca puisi pada siswa kelas V SD Negeri 8 Kusambi belum memuaskan, hal tersebut disebabkan oleh pembelajaran puisi yang masih diajarkan secara teoretis sehingga berdampak pada kurangnya minat dan motivasi belajar siswa terhadap puisi yang ditunjukkan dengan rendahnya hasil belajar siswa kelas $\mathrm{V}$ khususnya pada materi pokok membaca puisi yang masih berada di bawah standar ketuntasan minimal yang ditetapkan oleh sekolah yaitu 70 (ketuntasan individu). Data hasil ulangan harian tahun pelajaran 2015/2016 siswa kelas V SD Negeri 8 Kusambi menunjukkan bahwa dari 18 orang 
siswa, yang memperoleh nilai $\geq 70$ hanya 7 orang atau 38,9 \% dengan nilai rata-rata 62,27. Oleh karena itu, salah satu upaya untuk meningkatkan kemampuan membaca puisi bagi siswa kelas V SD Negeri 8 Kusambi adalah melalui penerapan pembelajaran kontekstual. Nurhadi dkk. (2002:13) menyatakan bahwa pembelajaran kontekstual adalah konsep belajar yang membantu guru mengaitkan antara materi yang diajarkannya dengan situasi dunia nyata siswa dan mendorong siswa membuat hubungan antara pengetahuan yang dimilikinya dengan penerapannya dalam kehidupan mereka sehari-hari. Pengetahuan dan keterampilan siswa diperoleh dari usaha siswa mengkonstruksi sendiri pengetahuan dan keterampilan baru ketika ia belajar. Pembelajaran berbasis CTL melibatkan tujuh komponen utama pembelajaran produktif, yakni: konstruktivisme (constructivism), bertanya (questioning), menemukan (inquiry), masyarakat belajar (learning community), pemodelan (modeling), dan penilaian sebenarnya (authentic assessment). Penelitian ini dimaksudkan untuk menemukan jawaban bagaimana cara meningkatkan kemampuan siswa kelas V SD Negeri 8 Kusambi dalam membaca puisi dengan pelafalan dan intonasi yang tepat dalam mata pelajaran Bahasa Indonesia melalui penerapan strategi pembelajaran kontekstual (CTL). Dengan penerapan CTL diharapkan timbul semangat dan kepercayaan diri siswa sehingga dapat menghayati dan membaca puisi dengan lafal dan intonasi yang baik dan benar.

Leni Widya (2013) dalam penelitiannya menyimpulkan bahwa kemampuan berbicara siswa dari siklus I ke siklus II mengalami peningkatan. Pada siklus I nilai rata-rata siswa mencapai 67,36. Setelah dilakukan tindakan siklus II, nilai rata-rata siswa meningkat menjadi 81,18. Ini menunjukkan bahwa dengan menggunakan model pembelajaran kontekstual ternyata lebih efektif dan mampu meningkatkan kemampuan membaca siswa kelas IV SD Negeri 11 Kendari Barat. Penelitian yang sama dilakukan oleh Yanti, dkk. (2016) berdasarkan hasil penelitian dapa disimpulkan bahwa terdapat pengaruh model pembelajaran kontekstua terhadap kemampuan koneksi matematika siswa kelas X SMA Negeri 4 Lubuklingau.

Berdasarkan uraian tersebut, penulis bermaksud menindaklanjuti dengan melakukan penelitian tindakan kelas dengan judul: "Meningkatkan Kemampuan Membaca Puisi Melalui Penerapan Pembelajaran Kontekstual Siswa kelas V SD Negeri 8 Kusambi”.

Masalah dalam penelitian ini adalah: Apakah kemampuan membaca puisi siswa kelas V SD Negeri 8 Kusambi dapat ditingkatkan melalui penerapan pembelajaran kontekstual? Tujuan penelitian ini untuk meningkatkan kemampuan membaca puisi siswa kelas V SD Negeri 8 Kusambi melalui penerapan pembelajaran kontekstual. Penelitian ini diharapkan dapat memberikan manfaat bagi guru, siswa, sekolah dan penelitian lainnya.

\section{Metode}

Jenis penelitian adalah penelitian tindakan kelas (PTK. Penelitian ini dilaksanakan pada semester ganjil tahun pelajaran 2016/2017 di SD Negeri 8 Kusambi Kab. Muna dengan Subyek dalam penelitian ini adalah guru dan seluruh siswa SD Negeri 8 Kusambi Kab. Muna Kelas V yang berjumlah 20 siswa. Penelitian tindakan kelas ini dilaksanakan dalam dua siklus yang terdiri dari empat tahapan yaitu perencanaan, pelaksanaan tindakan, observasi dan evaluasi serta refleksi Jenis data dalam penelitian ini adalah data kualitatif dan kuantitatif. Data kualitatif berupa kegiatan proses pembelajaran aktivitas belajar siswa dan aktivitas guru. Data kuantitatif berupa nilai hasil belajar siswa. Sumber data dalam penelitian ini adalah guru dan siswa Kelas V SD Negeri 8 Kusambi.

Data aktivitas guru dan siswa yang diperoleh melalui lembar observasi setiap siklusnya. Indikator keberhasilan dalam penelitian ini adalah kemampuan membaca puisi siswa dan keberhasilan proses pembelajaran. Siswa dikatakan telah memiliki kemampuan membaca puisi, apabila minimal $80 \%$ siswa telah mendapat nilai $\geq 70$. Proses pembelajaran 
dikatakan berhasil jika $\geq 80 \%$ proses pembelajaran dilaksanakan sesuai dengan skenario pembelajaran.

\section{Hasil}

1. Hasil Belajar Siswa

Hasil tes siklus I menunjukkan, bahwa sebanyak 14 orang siswa atau 66,67\% dengan nilai rata-rata 69,05 . siswa memperoleh nilai $\geq 70$ sedangkan siswa yang memperoleh nilai $\leq$ 70 sebanyak 7 orang siswa atau 33,33\%. hasil tes siklus II menunjukkan, bahwa sebanyak 20 orang siswa atau 95,24\% siswa memperoleh nilai $\geq 70$ sedangkan siswa yang memperoleh nilai $\leq 70$ sebanyak 1 orang siswa atau 4,76\%. Ini menunjukkan bahwa hasil belajar membaca sekilas siswa sudah mencapai ketuntasan kelas sebagaimana yang ditargetkan yaitu $80 \%$. nilai ketuntasan klasikal yang diperoleh siswa sudah mencapai $85 \%$ atau tujuh belas orang siswa yang memperoleh nilai di atas KKM atau $\geq 70$, dan masih terdapat tiga orang siswa atau $15 \%$ yang memperoleh nilai di bawah standar ketuntasan minimal, dengan perolehan nilai rata-rata secara klasikal yang dicapai siswa adalah 77,85

\section{Aktivitas Guru}

Nilai ketuntasan klasikal yang dicapai hanya $45 \%$ atau hanya Sembilan orang yang memperoleh nilai $\geq 70$, dan masih terdapat sebelas orang siswa atau $55 \%$ yang memperoleh nilai di bawah standar ketuntasan minimal, dengan perolehan nilai rata-rata secara klasikal yang dicapai adalah 65,05. Berdasarkan observasi kegiatan guru dalam proses pembelajaran siklus II, aktivitas guru mengalami peningkatan dibandingkan pada siklus I dan kekurangan yang terdapat pada siklus I telah diperbaiki serta terlaksana pada siklus II. Pada pertemuan pertama mencapai $64,70 \%$ dan pada pertemuan kedua mencapai $94,11 \%$.

3. Aktivitas Siswa

Berdasarkan observasi kegiatan guru dalam proses pembelajaran pada siklus I persentase aktivitas guru berdasarkan indikator-indikator yang terdapat pada lembar observasi aktivitas mengajar guru baru mencapai 58,82\%. observasi kegiatan siswa dalam proses pembelajaran siklus II juga mengalami peningkatan dibandingkan siklus sebelumnya. Pada pertemuan pertama mencapai $72,72 \%$ dan pada pertemuan kedua mencapai $90,90 \%$ dan aktivitas siswa berjalan sesuai dengan skenario pembelajaran.

\section{Pembahasan}

Dalam pelaksanaan pembelajaran siklus II disesuaikan dengan langkah-langkah pembelajaran kontekstual. Berdasarkan hasil evaluasi pembelajaran, penelitian ini berakhir setelah pelaksanaan siklus II karena tercapai indikator kinerja yang telah ditetapkan yaitu minimal 80\% tuntas dan memenuhi KKM 70.

Dari hasil yang diperoleh menunjukan bahwa indikator kinerja pada siklus I belum mencapai target yang ingin dicapai. Sehingga, penelitian dilanjutkan pada siklus II. Dimana, pada siklus II terjadi peningkatan hasil belajar siswa. Jumlah siswa yang tidak tuntas berkurang menjadi 3 siswa atau 15\%. Adapun siswa yang tuntas berjumlah 17 siswa atau $85 \%$ dengan nilai rata-rata meningkat menjadi 77,85\%. Dari hasil tersebut menunjukan bahwa indikator kinerja yang ingin dicapai telah tercapai dan penelitian ini berakhir pada siklus II.

Pada hasil observasi aktivitas mengajar guru di siklus II menunjukan peningkatan. Persentase keberhasilan aktivitas mengajar guru pada pertemuan pertama adalah $64,70 \%$ dan pertemuan kedua mencapai $94,11 \%$. Hasil tersebut sudah mencapai indikator kinerja yang ditetapkan yaitu minimal $80 \%$ aktivitas guru telah terlaksana dengan baik dan pertemuan berakhir di siklus II.

Melihat kekurangan yang masih ada serta hasil belajar siswa belum mencapai indikator $80 \%$, maka penelitian dilanjutkan di siklus II sesuai dengan perencanaan tindakan. 
Hal-hal yang harus diperbaiki pada siklus II, guru lebih memotivasi siswa untuk mengikuti pelajaran dan mengolah tahapan kegiatan pembelajaran dengan baik berdasarkan skenario pembelajaran dengan menggunakan model pembelajaran kontekstual. Hasil observasi keberhasilan aktivitas belajar siswa pada siklus II mengalami peningkatan dimana pada pertemuan pertama adalah $72,72 \%$ dan pada pertemuan kedua adalah 90,90\%. Sehingga, mencapai indikator kinerja yang diharapkan yaitu $80 \%$ aktivitas belajar siswa telah terlaksana dengan baik.

Pembelajaran kontekstual dapat dikatakan sebagai sebuah pendekatan pembelajaran yang mengakui dan menunjukkan kondisi alamiahdari pengetahuan. Melalui hubungan di dalam dan di luar kelas, suatu pendekatan pembelajaran kontekstual menjadikan pengalaman lebih relevan dan berarti bagi siswadalam membangun pengetahuan yang akan mereka terapkan dalam pembelajaran seumur hidup. Pembelajaran kontekstual menyajikan suatu konsep yang mengaitkan materi pelajaran yang dipelajari siswa dengan konteks dimana materi tersebut digunakan,serta berhubungan dengan bagaimana seseorang belajar atau gaya siswa belajar. (Trianto, 2011:104)

Dari kegiatan aktivitas mengajar yang dilakukan guru pada siklus I dan siklus II guru merasakan kelebihan dan kekurangan dalam menggunakan model pembelajaran kontekstual. Kelebihan menggunakan model pembelajaran kontekstual yaitu memungkinkan siswa untuk menguatkan, memperluas, dan menerapkan pengetahuan yang dimiliki sebelumnya. Proses belajar siswa dilakukan melalui pengamatan dan pengalaman yang dialami siswa baik dalam kelas, lingkungan sekolah maupun lingkungan tempat tinggalnya. Guru tidak perlu menjelaskan hal yang baru kepada siswa tetapi hanya mengembangkan pemahaman siswa kearah materi dan tujuan pembelajaran yang ingin dicapai. Adapun kekurangannya, guru sulit menghubungkan pengalaman siswa dengan materi pelajaran.

Dari pembahasan tersebut menunjukan hasil belajar siswa berupa keterampilan membaca puisi siklus I dan siklus II, hasil aktivitas mengajar guru siklus I dan siklus II serta hasil aktivitas belajar siswa siklus I dan siklus II telah mencapai indikator kinerja yang telah ditetapkan. Adapun hasil observasi terhadap pelaksanaan pembelajaran dikatakan baik sesuai dengan yang diharapkan. Karena hasil belajar siswa tuntas dan komponen dalam skenario pembelajaran telah dilaksanakan maka hipotesis tindakan telah tercapai yaitu.

1. Penerapan model pembelajaran kontekstual dapat meningkatkan keterampilan membaca puisi siswa kelas V SD Negeri 8 Kusambi.

2. Penerapan model pembelajaran kontekstual dapat meningkatkan aktivitas mengajar guru dalam pembelajaran Bahasa Indonesia pada siswa kelas V SD Negeri 8 Kusambi.

3. Penerapan model pembelajaran kontekstual dapat meningkatkan aktivitas belajar siswa kelas V SD Negeri 8 Kusambi.

\section{Simpulan}

Berdasarkan hasil penelitian dan pembahasan dapat diambil kesimpulan sebagai berikut. Penerapan pembelajaran kontekstual dalam pembelajaran Bahasa Indonesia pada materi membaca puisi pada kelas V SD Negeri 8 Kusambi dapat meningkatkan kemampuan membaca puisi siswa. Hal ini tampak pada persentase ketuntasan belajar siswa yang diperoleh pada tiap siklus. Nilai rata-rata siklus I mencapai 65,05 dengan persentase ketuntasan secara klasikal mencapai 45\% (hanya 9 dari 20 orang siswa yang memenuhi kriteria ketuntasan minimal 70). Pada siklus II nilai rata-rata meningkat menjadi 77,85 dengan persentase ketuntasan secara klasikal 85\% (17 dari 20 orang siswa telah memenuhi kriteria ketuntasan minimal).

Penggunaan pendekatan pembelajaran kontekstual pada pada kelas V SD Negeri 8 Kusambi telah berhasil diterapkan di dalam kelas terlihat pada aktivitas mengajar guru dengan 
menggunakan pendekatan pembelajaran kontekstual, pada tindakan siklus I pertemuan pertama mencapai $47,05 \%$ dan pertemuan kedua mencapai 58,82\%. Aktivitas mengajar guru meningkat pada tindakan siklus II pertemuan pertama mencapai $64,70 \%$ dan pertemuan kedua mencapai 94,11\%. Dapat disimpulkan bahwa aktivitas mengajar guru terlaksana dengan baik. Penggunaan model pembelajaran kontekstual dapat meningkatkan aktivitas belajar siswa. Dilihat pada tindakan siklus I pertemuan pertama aktivitas belajar siswa mencapai $45,45 \%$ dan pertemuan kedua mencapai 54,54\%. Pada tindakan siklus II aktivitas belajar siswa meningkat pada pertemuan pertama mencapai $72,72 \%$ dan pertemuan kedua mencapai $94,11 \%$.

\section{Referensi}

Budianta, Melani. 2002. Membaca Sastra. Depok Indonesia.

Nurhadi,et.al. 2002. Pembelajaran Kontekstual dan Penerapan dalam KBK. Malang: Universitas Negeri Malang.

Sakdiyah. 2001. Sastra Indonesia. Jakarta: Gramedia.

Susanto, Ahmad. 2014. Teori Belajar \& Pembelajaran di Sekolah Dasar. Jakarta: Kencana Prenadamedia Group.

Trianto. 2011. Model-Model Pembelajaran Inovatif Berorientasi Konstruktifistik. Konsep, Landasan Teoretis-Praktis dan Implementasinya. Jakarta: Prestasi Pustaka Publisher.

Widya, Leni. 2013. "Meningkatkan Kemampuan Berbicara Siswa Kelas IV SD Negeri 11Kendari Barat dengan Menggunakan Model Pembelajaran Kontekstual". Skripsi Universitas Haluoleo.

Yanti, D., dkk. (2016) Pengaruh Model Pembelajaran Kontekstual Terhadap Kemampuan Koneksi Matematika Siswa Kelas X SMA Negeri 4 Lubuklingau Tahun Pelajaran 2015/2016. Jurnal Pendidikan Matematika Raflesia Vol. 2 No. 2. https://ejournal.unib.ac.id/index.php/jpmr/article/view/3698/1939. 